\title{
Payments for environmental services and motivation crowding: towards a conceptual framework
}

\author{
Driss Ezzine-de-Blas ${ }^{a, b *}$, Esteve Corbera ${ }^{c}$, Renaud Lapeyre ${ }^{d}$ \\ ${ }^{a}$ CIRAD, UPR Forêts et Sociétés, Campus international de Baillarguet, 34398 Montpellier, France. \\ ${ }^{\mathrm{b}}$ Montpellier University, Montpellier, France \\ c Institute of Environmental Science and Technology (ICTA), Universitat Autònoma de Barcelona, ICTA-ICP, \\ Edifici Z, Carrer de les Columnes, Campus de la UAB, 08193 Bellaterra (Cerdanyola del Vallès), Barcelona, \\ Spain \\ ${ }^{d}$ Institute for Sustainable Development and International Relations (IDDRI), 75006 Paris, France \\ * Corresponding author. \\ E-mail addresses: ezzine@cirad.fr (D. Ezzine-de-Blas), esteve.corbera@uab.cat (E. Corbera), \\ renaud.lapeyre@iddri.org (R. Lapeyre).
}

\begin{abstract}
Research on Payments for Environmental Services has only recently started to pay attention to motivation "crowding", i.e. the effect that such rewards might have on either strengthening (crowding-in) or weakening (crowding-out) participants' intrinsic motivations to protect and sustainably manage natural ecosystems. In this Introduction to the special issue Crowding-out or crowding-in? Behavioral and motivational responses to economic incentives for conservation, we propose a conceptual framework that maps out how PES implementation, or incentive-based conservation more broadly, might lead to motivation and behavioural change, drawing on theoretical insights and empirical evidence from behavioural economics and social psychology. We also explain how PES design and implementation factors, such as payment type, communication and verbal rewards, inclusive and participatory decision-making, and monitoring and sanctioning procedures, might harm or enhance intrinsic motivations. We suggest that motivation crowding depends on how these policy features are perceived by and affect an individual's need for satisfaction, modulated in turn by the stimulation or inhibition of competence, autonomy, social and environmental relatedness. We highlight the importance of measuring these variables and their motivation and behavioural outcomes in future PES research, in order to relate psychological processes with other contextual determinants of PES social-ecological performance.
\end{abstract}

\section{Introduction}

Understanding why we act the way we do has been a subject of reflection for centuries by philosophers, economists, sociologists, psychologists and, more recently, neuroscientists (Koob et al., 2010; Thaler, 2015). Economists have traditionally advocated the maximization of a person's utility function as the guiding principle for understanding human behaviour (Heukelom, 2015). Such a principle has been one of the foundations for the use of both cash and in-kind incentives to foster biodiversity conservation and the sustainable management of natural resources (Ferraro and Kiss, 2002). A salient approach in this regard has been the so-called Payments for Environmental or 
Ecosystem Services (PES). PES consist of persuading "beneficiaries" of certain ecosystem services (e.g. watershed regulation, soil conservation, carbon sequestration) to channel money and/or inkind rewards (also called, often interchangeably, incentives and payments), to service "providers" who should in exchange implement practices that, in theory at least, would result in the increased provision of the desired services (Wunder, 2015; Sattler et al., 2013).

It has been commonly assumed that landowners and rural communities will voluntarily participate in PES if the incentives received up-front or ex-post are direct and cover the opportunity costs and hence result sufficiently attractive to undertake the required activities for the provision of ecosystem services (Tacconi, 2012). In other words, ecosystem service "providers" should behave as rational actors who calculate the benefits and costs of conservation versus other alternative land-use options and act upon accordingly (Laffont and Martimort, 2002). It has also been emphasized that PES schemes ought to be efficient, which means they should provide the targeted ecosystem service -or ecological proxy- at the minimum cost, and they also should be additional, which means that payments must generate a genuine ecological improvement (Engel et al, 2008; OECD, 2010). In spite of such theoretical simplicity and appeal, research and practical experiences have shown that PES implementation has been a rather "messy" endeavour, in which the sociopolitical and cultural complexities of the countries, territories and localities where PES have been implemented have taken central stage in its design and implementation (Muradian et al. 2013; Engel, 2016; Ezzine-de-Blas et al., 2016a).

Such complexities have revealed, at least, four shortcomings of the "appealing" PES approach. First, the targeting of ES "providers" depends on multi-level governance arrangements where efficiency and additionality principles often play a secondary role, submerged by the influence of multiple intermediaries, power struggles and by the pursuit of procedural and distributive privileges (Pascual et al., 2014; Ezzine-de-Blas et al., 2016b; Corbera et al., 2007). Second, estimating providers' opportunity costs can be challenging given the methodological difficulties of estimating real opportunity costs instead of modelled or stated ones (Brimont et al., 2017), what has made the calculation of precise cost-and-benefit baselines a rather difficult enterprise in both developing (Wunscher et al., 2008; Borrego and Skutsch, 2014) and industrialized countries (Claassen et al., 2008). Third, some have highlighted that PES participants might accept to conserve even with payments falling below their land-use opportunity costs, driven by a non-economic rationale and a set of alternative motivations (Kosoy et al., 2007). And, finally, it has been noted that PES might erode the social institutions, cultural values and motivations that sustain a non-utilitarian view of biodiversity conservation and natural resource management in some contexts (McCauley, 2006; Arsel and Buscher, 2012; Peluso, 2012; McAfee, 2012; Kosoy and Corbera, 2010).

Generally speaking, motivations to participate in a given activity, such as a PES, can be broadly classified in intrinsic and extrinsic. The former implies doing something because it is inherently interesting or enjoyable, regardless of anything else. Extrinsic motivations, in turn, involve a diversity of reasons external to oneself, including punishments, such as fines, or incentives, such as cash or in-kind rewards (Ryan and Deci, 2000b). Intrinsic and extrinsic motivations are not mutually exclusive, which means that a combination of both might explain in some instances why one acts in a specific way. In the PES literature, as noted above, some have hinted at the possibility that PES weaken people's intrinsic motivations to conserve -i.e. crowd out- over time, leading individuals to participate in conservation exclusively driven by extrinsic reasons (Rico Garcia-Amado et al., 2013; Rode et al., 2015), while others have suggested that payments might reinforce intrinsic motivations -i.e. crowd in-, potentially making participants intrinsically more conservation pro-active (Dedeurwaerdere et al., 2016). Whichever the nature of motivation crowding, the alleged direct causality between changes in motivations and behaviours might not always hold, since some studies have suggested that motivations and behaviours are not always aligned (Steg and Zlek, 2009; Schluter, 2017). 
Investigating the effect of PES design and implementation on individual motivations and conservation behaviour is the focus of this special issue. This introductory article has three objectives: (i) to review the main theoretical underpinnings and research findings from behavioural economics and social psychology, disciplines which have extensively focused on the study of the interactions between intrinsic and extrinsic motivations to explain human behaviour (section 2); (ii) to develop a conceptual framework that reflects on the relationship between PES implementation and motivation crowding, paying attention to the different contextual scales in which PES operate (section 3); and (iii) to discuss the findings of the special issue articles in the light of the proposed framework (section 4). The article concludes identifying some knowledge gaps and methods that could guide PES research in the future (section 5).

\section{Motivation crowding through the lens of behavioural economics and social psychology}

Titmuss (1971) was the first to address motivation crowding out in the context of blood donation campaigns: his findings suggested that people were less keen to donate blood if provided with an economic incentive. Since then, a large number of economic experiments in the education, industry and health sectors have demonstrated the effect of economic incentives on motivations to perform a given task (Frey and Oberholzer-Gee, 1997; Gibbons, 1998; Frey and Jegen, 2011; Gneezy et al., 2011). Economists have found intrinsic motivations to crowd out when incentives are introduced for activities that used to happen without such incentives, such as for collective activities (Ostrom, 2000; Houser et al., 2008; Bracht and Feltovich, 2008) and reciprocal behaviour (Fehr and Gachter, 1997; 2002). Similarly, payments that substitute for social norms can also crowd out intrinsic motivations (Gneezy and Rustichini, 2000). Sanctions and monitoring -a key feature of PES- crowd out intrinsic motivations if they are perceived as a signal of distrust or as a limitation of one self's freedom, in particular when work settings involve interpersonal relationships (Dickinson and Villeval, 2008; Ellingsen and Johannesson, 2008; Falk and Koskfeld, 2006). The only exception being that, when control limits free riding, such control can increase the feeling of fairness of the reward and subsequently offset crowding-out effects (Dickinson and Villeval, 2008).

Whereas behavioural economics have demonstrated that external incentives induce mainly motivation crowding-out, the opposite outcome happens in other but less frequent cases (Le Grand, 2006; Meyer and Gagné, 2008). For example, in a review from laboratory and field experiments, Frey and Jegen (2001) find that external incentives crowd in motivations when their implementation draws on pre-existing trust among actors. In other cases, the evidence of the relationship between external incentives and motivations is less straight forward, what attests of their complex interactions. For example, while some studies point out that rewarding economically the pro-social values of volunteering activities increases volunteers' intrinsic motivations and performance (Thomas et al., 2009; Fiorillo, 2011), others show a net decrease without a precise identification of the underlying mechanism that might explain such different outcomes (Frey and Götte, 1999). In the context of blood donation, Le Grand (2006) found that payments and motivations follow an S-shaped curve: while a little payment increases blood donation levels, at some point the payment impacts intrinsic motivations negatively and decreases such levels. Very high payments become then necessary to boost blood supply again.

When dealing specifically with pro-environmental behaviour, economic theories and experiments have recently mounted in the areas of industrial, water and waste management, recycling, and mobility and consumption decisions (Frey, 1992; 1993; Frey and Oberholzer-Gee, 1997; Brekke et al., 2003; Bowles, 2008). In the field of ecosystem services, Rode et al. (2015) review eighteen empirical studies published after 2013 dealing with the impacts of tradable quotas, environmental taxes, subsidies and payments for biodiversity conservation on resource managers' motivations. They identify seven psychological mechanisms that induce motivation crowding-out and four 
leading to crowding-in. Among the studies reviewed, eight relate to PES schemes. Like prior reviews, the authors suggest that crowding-out is more frequent than crowding-in but that the understanding of the causal mechanisms behind the shift in motivations remains poor. One of the possible explanations for such poor understanding is the lack of a shared analytical framework that would allow comparing metrics, research protocols and results to unravel the nature of such mechanisms. In sum, behavioural economics studies have focused on understanding how motivation crowding-out affects performance and the supply of services under different contextual situations, but without discerning in detail the underlying psychological mechanisms behind motivational change and without making a clear distinction between motivations and behaviours.

Social psychology has approached motivation crowding as an understanding of what governs our actions, giving a specific place to the role of motivations in order to reach a theoretical formulation of the causal mechanisms governing motivation crowding-out. The fist theory to make explicit the link between external incentives and motivations was Cognitive Evaluation Theory (CET), which in turn draws from the combination of two former theories, i.e. the locus of control (Rotter, 1954; 1966) and the theory of the perceived locus of causality (deCharms, 1968). While the former discusses if a person understands the control of her/his life as being dependent on oneself or placed outside her/his control, the second discusses the extent to which individuals perceive their actions as caused by internal or external reasons. Cognitive Evaluation Theory (CET) results from the combination of these two theories and was the first referring to motivation crowding. CET states that a person will feel more intrinsically motivated if she/he perceives the locus of causality of performing an action as being internal. This means that an individual intrinsically motivated performs an action for the pleasure of doing it -i.e. because of experiencing her/his competence on the task - and because of being free to decide -i.e. autonomous. These two psychological dimensions are central concepts in the special issue: while competence in CET means an increase or recognition of our ability to do something, autonomy refers to our perception of how much we think we master our decisions. Hence, the main theoretical prediction of CET was that any externally driven economic incentive designed to achieve an outcome would decrease intrinsic motivations if it eroded autonomy (Deci, 1975).

CET was further developed in the so-called Self-Determination Theory (SDT), which analyses more in detail the role that these psychological dimensions -e.g. feeling of autonomy and competence-, might play in determining the loss of intrinsic motivations. These psychological dimensions, referred to as moderators in SDT, encompass the above-mentioned sense of autonomy and feeling of competence, as well as the self-evaluation of our interactions with others -i.e. social relatedness (Deci and Ryan, 1991; Ryan and Deci, 2000a). Social relatedness in SDT refers to our feeling of social belongingness, that is how we perceive our connection to, and experience caring for others (Baumeister and Leary, 1995). As such, it represents a bold psychological dimension for PES implementation and another central concept addressed by our special issue. Furthermore, SDT posits that an individual's distinctive activation of these moderators can explain the enhancement or decrease of her/his psychological satisfaction when performing a given task. Because SDT describes such psychological satisfaction as a people's basic need, it is normally referred to as psychological need satisfaction or need satisfaction (Deci and Vansteenkiste, 2004). From this perspective, any change on such need satisfaction moderators caused by, for example, a given external reward or punishment, could trigger a psychological response (e.g. frustration, release from moral responsibility, increased confidence) that may ultimately explain a gain or loss in intrinsic motivations. An additional important feature of SDT is the self-determination continuum. This continuum presupposes the existence of a motivational axis that encompasses one's complete demotivation to perform a given task in one extreme and one's unique intrinsic motivation in another. Such a conceptualization allows representing motivation crowding-out as the relative "move" induced by the norm, incentive or policy towards the demotivation extreme; in contrast, motivation crowding-in implies "moving" in the opposite direction (Gagné and Forest, 2008). The 
existence of the self-determination continuum also presupposes that external regulations or incentives can be internalized: if they align with the three psychological moderators, external regulations can be progressively assimilated as something we perform for its intrinsic importance.

Although alternative works in social psychology propose other theories to explain proenvironmental behaviour -such as the over-justification hypothesis ${ }^{1}$ (see e.g. Lepper et al., 1973), the Theory of Planned Behaviour (Ajzen, 1991) and the Value-Belief-Norm Theory (Stern et al., 1999)-, SDT has been acknowledged by many contemporary social psychologists as the most accurate explanatory framework to explain motivation crowding (Festré and Garrouste, 2014). Some have tested SDT postulates through laboratory experiments ${ }^{2}$-mostly with undergraduate psychology students-, and others through natural field experiments (Festré and Garrouste, 2014). In their meta-analysis of 128 studies exploring the motivation crowding effect of verbal versus economic incentives, Deci et al. (1999) found that economic incentives decreased intrinsic motivations, although the effect varied depending on the type of population and level of economic reward. For example, verbal incentives increased intrinsic motivations but only for college students when compared to children. On average, monetary rewards decreased intrinsic motivations, but performance-based payments were less detrimental. Deci and colleagues also discuss that, although incentives are normally felt as an imposition and thus translate into a decrease in intrinsic motivations, they can also be perceived as fair and legitimate, which leads to the strengthening of intrinsic motivations. Such a two-sided effect depends on the incentive characteristics, the type of task to be accomplished (e.g. boring vs. stimulating), the individual's social characteristics (e.g. level of education, gender, age), and the interpersonal context, including institutions and cultural values. In contrast with behavioural economics, social psychology has advanced an explicit theoretical model to explain motivation crowding-out, focusing on the underlying mechanisms behind changes in motivations.

\section{A conceptual framework to understand motivation crowding in PES}

We now turn to present a conceptual framework that can help us analyse motivation crowding in PES. The framework enlarges SDT in three aspects. First, it includes an additional psychological moderator that we call 'environmental relatedness' (table 1), which accounts for the human feeling of belonging to a natural setting or landscape (d'Adda, 2011; Greiner and Gregg, 2011; Fisher, 2012). Second, our framework integrates the influence of policy design and the impact of motivations on performance, research dimensions frequently present in the behavioural economics literature. And third, we include the influence of the larger individual -education and culture- and social-social norms, institutions and markets- context. By proposing a specific conceptual framework for understanding motivation crowding in PES we aim to describe how PES design features, such as monitoring and sanctioning, type and amount of economic incentives, interaction with local and larger institutions, and participatory and collective management mechanisms, might cognitively affect participants' moderators (Sattler et al., 2013; Dedeuwardeare et al., 2016).

FIGURE 1 COMES HERE

Figure 1. Motivation crowding pathways in PES. The asterisk $\left({ }^{*}\right)$ indicates the undermining effect.

\section{TABLE 1 COMES HERE}

\footnotetext{
${ }^{1}$ According to self-perception theory, a person infers causes about his or her own behavior based on external constraints such as an external incentive or reward. When given, it leads a person to conclude that he or she is performing the activity solely for the reward, which shifts the person's motivation from intrinsic to extrinsic.

${ }^{2}$ Laboratory experiments usually measure intrinsic motivation as the time spent in the experiment task during a break between two periods of time in which the experiment task is obligatorily performed.
} 
Figure 1 represents our conceptual framework. It highlights the relationships between PES design and implementation features (left-hand side shaded box), and the institutional context in which PES operate (central, dotted areas), with motivation crowding-in or crowding-out processes (central area). These processes are influenced by need satisfaction moderators (left-hand side boxes) and they result in distinct degrees of PES long-term performance (right-hand side boxes).

The figure is grounded on the premise that PES design and implementation, including PES application and participation criteria, payment levels, or monitoring and enforcement activities, combined with both personal and contextual conditions, such as education, wellbeing, collective action and broader institutions, will activate participant's need satisfaction moderators (Table 1). This first step is expressed in the extreme left of the causal mechanism arrow as Activators (PES implementation). PES implementation cognitively interacts with these moderators in the participant's central valuation brain system (Murayama et al., 2010). Such interaction forms the second step in the causal mechanism of the conceptual framework and is described as Interaction between moderators. This interaction can be seen as a psychological mechanism, that is, a mental and emotional pattern that originates in a given situation. The outcome -which we describe as the Psychological evaluation outcome- will be either an increase or a decrease in the participant's need satisfaction level. According to the SDT continuum, if intrinsic motivations increase then extrinsic motivations automatically decrease. The opposite holds too and is described in the causal arrow of the framework as a Motivational change.

The fifth step in the causal sequence relates with behaviour during PES implementation (i.e. Behavior short-term in the framework). Existing evidence on the link between external incentives, intrinsic motivations and behaviour shows that during PES implementation, conservation usually improves: Indeed, during PES implementation, conservation behaviour increases either because participants are stimulated only by extrinsic motives, or by only intrinsic motives or by a combination of both (Andersson et al., 2018; Borner et al., 2016). How these different configurations affect conservation performance during PES implementation is difficult to be explained and existing evidence does not allow us to be conclusive. However, the sixth and last step in our causal sequence (Behavior long-term in the framework) posits that, after the end of the programme, we can expect conservation behaviour to get back either to pre-PES levels or even to a lower level (Andersson et al., 2018; Borner et al., 2017). This potential negative time-lagged of motivation crowding-out or undermining effect can potentially be one of the major drawbacks of PES implementation. Undermining effect happens therefore when motivation crowding-out provokes post-PES conservation performance to fall below conservation levels before PES. This potential impact of PES on both motivations and behaviour in the longer term expresses a move of the individual's overall bundle of motivations along one of the sides of the self-determination continuum, represented in our framework at the bottom right. A net increase in intrinsic motivations moves the individual's bundle of motivations towards the extreme of the axis dominated by only extrinsic motivations - represented with a minus in the axis. A decrease in intrinsic motivations moves the individual's motivations towards the other extreme of the axis, dominated by only extrinsic motivations -represented with a plus in the axis.

Finally, as previously mentioned, the conceptual framework posits that the effect that PES implementation might have on need-satisfaction moderators will respond to each individual background, including the educational and cultural context and the larger inter-personal and institutional setting. As such, the framework contains two embedded scales: the individual scale and a broader, contextual scale that includes institutions (e.g. social norms, markets) and cultural values that interact with each other and co-evolve.

\section{Operationalizing the framework: insights from the special issue}




\subsection{Methods and metrics}

The seven articles included in this special issue present the results of research performed in SouthEast Asia (India and Cambodia), Central-Asia (Kyrgyz Republic), East Africa (Tanzania) and Latin America (Nicaragua and Colombia). All articles deal with PES, except for one article that studies an organic certification premium-price scheme, and they focus on the effects of a real or hypothetical PES intervention on motivation crowding. In doing so, four articles use framed-field experiments, one article deploys quasi-experimental methods that quantitatively evaluate the impact of "real" ongoing PES schemes and two articles use ethnographic methods (Table 2). The first set of four articles use role games and framed field experiments to study the interaction between payment design, motivations and behaviours. Each article adopts a different proxy for conservation behaviour, which the authors assume to reflect motivations. Proxys for conservation behaviour include tree-harvesting rates (Handberg et al.) and land forest conservation decisions (Kaczan et al., Moros et al. this issue).

Kaczan et al. (this issue) implement a modified dictator game where forest conservation decisions run under four different policy treatments (individual PES, collective PES and two mandatory conservation levels) to test for the undermining effect. Handberg et al. (this issue) use a common pool forest game in Tanzania to test for the impact of different payment levels on motivation crowding-out. The authors also test for the role of competence, social and environmental relatedness to predict changes in intrinsic motivations. Moros et al. (this issue) develop a public good game with threshold and confront the game outcomes with a post-experiment survey on motivations to test for the role of autonomy, competence and collective action in reinforcing intrinsic motivations. Moreover, the authors conduct a specific post-experiment survey to investigate if a change in motivations correlates with a change in the conservation behaviour observed in the experiment. Kolinjivadi et al. use a framed field experiment to analyse qualitatively how skill recognition and community inclusiveness motivates young villagers to enrol in the experiment.

In the only article using quasi-experimental methods, Chervier et al. (this issue) implement a control-treatment approach with matching to quantify the impact of payments for biodiversity conservation in Cambodia on declared pro-environmental perceptions and on the probability of breaking conservation rules after the end of the contract -another proxy to detect an undermining effect. Finally, the last two articles use an ethnographic protocol to analyse the role of the context in terms of norms and institutions when it comes to understand what other enabling factors are needed for PES to change motivations. Bose et al. (this issue) analyse the variety of motivations behind the will of farmers to engage in the price-premium certification scheme proposed by the Rainforest Alliance. Van Hecken et al. disentangle how motivations co-evolve with productive systems in a wider agrarian territorial context.

These distinctive articles provide insights on what methods fit best for each specific research question and data availability. Framed field experiments and quasi-experimental methods allow formulating need satisfaction moderators and crowding mechanisms in quantitative terms. Besides, the variety of ways to formulate a game allows controlling for the different specifications of PES design. However, given the highly controlled environment in which they are played, framed field experiments are criticized for having a limited external validity. Only Handberg et al. test for external validity, with positive results for the specific context where the experiment is performed. Qualitative studies allow to better integrate the influence that the context might have -e.g. in terms of governance dynamics and institutions- in enabling a change in intrinsic motivation given a particular PES design. Nevertheless, these studies do not offer a quantitative measure of the impact on motivations and conservation. Quasi-experimental methods seem to meet the weakness the other methods have: they have a strong external validity, need a solid qualitative understanding of 
the context and offer a quantitative measure of impact. However, they are expensive to carry, the experimental design needs a strong political support from the implementing organization and the robustness of their estimations depends on the reliability of the control units.

This methodological diversity also points out to the relevant challenge of which "metrics" to use when aiming to understand motivation crowding. Authors in the special issue and in the literature reviewed above tend to omit the discussion on the alleged direct causality between motivation crowding and a change in behaviours. For practical and data availability reasons, both Handberg et al. and Kaczan et al. mechanically associate participants' behaviour in their experiments -a highest tree-harvesting rate or a larger conversion of forest to agricultural land respectively- with a change in participants' motivations. Likewise, Chervier et al. use stated perceptions and suggested future behaviours as a proxy for motivations. Such challenge will need to be tackled in future research if one really aims at better understanding PES theory of change. Only Moros et al. test the correlations between the behaviours recorded in the experiment and stated conservation motivations emerging from a post-experiment survey. A similar challenge emerges when defining proxies for need-satisfaction moderators. For example, Handberg et al. use the presence of a relative in the experimental room as a proxy for social relatedness while Moros et al. use personal statements from the motivation survey, like "I would be criticized by my neighbours if I clear the forest", as a proxy for social relatedness.

\section{TABLE 2 COMES HERE}

\subsection{Motivation crowding}

Compiling and comparing research result when different research methods and hypotheses are mobilised across the articles included in this special issue proves a difficult task. To do so, in table 2 we aimed at systematizing and conceptualizing such results by representing motivation crowdingout our motivation crowding-in as a function of the moderators and sub-moderators proposed in our framework, in order to compare the empirical results in a qualitative manner. Main findings are summarised thereafter.

Kaczan et al. find on average no evidence for an undermining effect under the four treatments but a strong and persistent motivation crowding-in for the mandatory treatment. The authors explain this result as a possible framing effect in which the participants of the mandatory treatment perceive the top-down prescriptive behaviour as a socially appropriate one -i.e. it is internalized as a new social norm. Nevertheless, when comparing the effects of the different treatments with the socio-economic characteristics of participants they find both crowding-in and crowding-out to coexist. Although motivation crowding-in is more significant that crowding-out, the former is particularly relevant given the large number of foreign landowners involved in PES.

Øyvind and Angelsen's also do not find on average a statistically significant support for motivation crowding-out under PES. Their results show that when no or low payments are offered, the real level of conservation is higher than predicted, revealing the existence of intrinsic and other intangibles in explaining conservation behaviour at low opportunity costs (Kosoy et al., 2007). Besides, their results underscore that increasing payments has a negative, but diminishing effect on harvest rates, but find no support of SDT moderators in explaining it: participants have a noncompressive minimum forest harvest need -e.g. for subsistence or fuelwood- that is not interchangeable with a payment. However, as a source of caution, the perceptions and statements of the authors' post-experimental survey suggest that payments could make traditions, culture and religion less important in the long-term. 
Moros et al. find that while forest conservation increases under all payment types, the crop-price premium scheme fosters motivation crowding-out while collective payments induce motivation crowding-in. They suggest, however, that -during the experiment- an increase in intrinsic motivations does not directly imply an increase in conservation behaviour or vice-versa. In the reallife experimental setting of the Kyrgyz republic case study, Kolinjivadi et al. confirms the link between motivation crowding-in and collective PES if the latter aligns with social norms and the social capital is strong. They define such alignment as a synergistic positive shift that strengthens intrinsic motivations. Nevertheless, antagonistic shifts can also occur if collective benefits or payments are implemented in a context of mistrust. Individual motivations and collective norms are in continued interaction, and a challenge in PES design is to follow and adapt to such feedbacks.

In the Cardamom Mountains of Cambodia, Chervier et al. find that the implementation of a real PES programme brings a new social-environmental paradigm in terms of semantics and social norms, in sharp contrast with their cultural values. As a result, PES shifts participants' perceptions of forest values from use values to monetary values. Moreover, at the individual level, if PES is perceived as colluding with pre-existing power inequities and the unfair distribution of conservation costs and benefits, motivation crowding-out is stronger and persisting after the end of the scheme. Chervier et al. results suggest that statements on future actions express a reliable intention of breaking forest conservation norms in individuals that before entering the PES scheme were respecting it i.e. an expression of the undermining effect.

Using an ethnographic approach, Bose et al. shows more nuanced results when dealing with motivations to join the Rainforest Alliance coffee certification. Authors show that participation can only be appropriately understood if taking into account a hybrid framework where both intrinsic and extrinsic motivations are at work. Their results show that while non-economic reasons to participate link to intrinsic motivations, economic reasons can mobilize both intrinsic -upgraded farm management, more knowledge- and extrinsic -pure financial gain- motivations. Besides, the authors point out at two important aspects: the importance of certification as a way to reach more autonomy by gaining negotiation powers at state level; and the importance between the long-term vs short-term framing of policy interventions, with short-term interventions being more prone to crowd out intrinsic motivations and enrolment. Finally, van Hecken et al. deepens on how productive and conservation motivations are embedded in a larger rural territorial context by applying an agrarian system approach. Such approach allows underscoring that the implementation of the PES scheme actually failed to alter the motivations of farmers, mostly because the design neglected larger contextual regional and historic development pathways of resource and forest use where the improvement of cattle activities is at the core of collective and individual motivations.

\subsection{Accounting for motivational mechanisms in PES design}

Based on the contributions to this special issue and PES literature, Table 3 summarizes how need satisfaction moderators might be related to PES design features (as in figure 1). First, we observe that one of the recurrent mechanisms tested in our special issue is if collective PES rewards are more likely to foster motivation crowding-in than individual rewards. It appears that in a context where social capital is strong -i.e. reciprocity norms exist, people trust each other, and leaders are respected, collective PES can increase intrinsic motivations (Andersson et al., 2018; Bottazzi et al., 2018). However, the opposite holds also true if social conflicts are widespread and leaders are not respected (Costedoat et al, 2016). These results can be justified on the grounds of an interaction between social relatedness moderators and the institutional context in which PES is developed. If social capital is strong, a PES programme that considers social relatedness moderators might be able to foster motivation crowding-in, by engaging in collective work and investments - for example- when participants trust each other, local institutions and leaders (Table 3 ). In contrast, if social conflicts challenge the reliability of local institutions, investments and activities benefiting the 
group might not be well perceived. In this case, relying on individual motivations such as autonomy and competence offers more chances of activating intrinsic motivations (Gert et al. this issue). In a nutshell, an analysis of social capital prior to PES design, we believe, can help promoters align moderators with the type of payments, either collective or individual .

Table 3 also makes evident that although the environmental relatedness moderator has not been a central matter of concern in the articles of the special issue, when tested, it has provided interesting insights. For example, in the latent class model of Kaczan et al. (this issue), foreign landowners are more prone to depend on extrinsic motivations to behave pro-environmentally. Similarly, Bose et al. (this issue) find that the will to have the name "Kogadu" in the certified coffee was an important motivation to participate.

In line with the moderator on environmental relatedness, the importance of autonomy has not been systematically analysed by the special issue contributions. In fact, when explicitly tested it did not have a strong effect: Moros et al. (this issue) introduce a treatment that includes a voting option, but it did not affect motivational outcomes. Bose et al. (this issue) posit that coffee producers see the certification process as a way of gaining more autonomy with respect to the central government. The role played by autonomy, in particular by designing the PES in a participatory way, has also not been widely tested by the research papers of the special issue. Emerging PES literature on motivations shows that an inclusive participation favours intrinsic motivations (Dedeurwaerdere et al., 2016). Chervier et al. (this issue) find that the top-down conservation approach led by an international NGO fosters a monetary perception of forest conservation. Moros et al. (this issue) find no effect on motivations when introducing in the framed field experiment the option to vote the type of payment design. One possible complexity for understanding the effect of autonomy on motivations to conserve is the fact that how an individual perceives the ability of being autonomous depends not only on the possibility of making individual choices but also on how meaningful these individual choices are at the collective and institutional levels (interpersonal context in figure 1).

Competence appears as an important moderator in a number of articles from the special issue. Bose et al. (this issue) and van Hecken et al. (this issue) identify excellence in land management skills as key individual motivators among coffee growers and cattle ranchers. PES can be perceived as a recognition of existing competences or as a way to improve participants' skills: in both cases the feeling of being competent at the individual level seems to strengthen intrinsic motivations. Such a recognition of effort and capacities can also be supported by the recognition of a wider social group, when such group is respected (Kolinjivadi et al. this issue).

\section{TABLES 3 COMES HERE}

Overall, the articles gathered by the special issue show that motivations to conserve depend on the emotional multi-dimensionality of an individual, situated in a particular socio-institutional and environmental context. This implies that psychological mechanisms leading to motivation crowdingout and motivation crowding-in can co-exist within a group of participants (Kaczan et al. and Moros et al. this issue) but also for a same individual (Bose et al., this issue). Hence, the observed conservation behaviour emerges from the aggregation of different motivations, making behavioral patterns rather unstable and unpredictable, so far.

\section{The future of PES and motivation crowding research}

In this article, we have drawn on SDT and insights from behavioural economics to develop a conceptual framework for the study of PES and motivation crowding. We believe that such framework can improve our understanding of the relationship between conservation incentives 
and human behaviour and motivations, as well as it can aid the (re-)design of PES programmes. Based on the framework and the insights of the special issue, we have argued that, during PES implementation, conservation behaviour frequently improves, either driven by extrinsic or intrinsic motivations. However, once payments are removed, it is likely that extrinsically motivated individuals adopt a lower conservation behaviour compared to the pre-PES period. The latter is the so-called undermining effect of PES, which can put at risk the long-term additionality of PES initiatives (Börner et al., 2017). We have also argued that such motivations are by no means static; PES design and implementation features, including an inclusive design through participation measures, an alignment with local institutions, or the support of individuals' personal development can recraft both intrinsic or extrinsic motivations. But these motivations can also change as a result of changes in the personal and interpersonal context.

We are aware that our propositions above need to be further validated by future research. In particular, more research on the role that autonomy and competence can play in conservation performance and the long-term sustainability of PES and other incentive-based conservation programmes should contribute to overcome a bias towards the analysis of pro-social and environmental relatedness as key moderators of behavioural and motivational change.

The special issue contributions also reflect the variety of qualitative and quantitative methodological approaches that, either combined or alone, can help advance this research agenda. On the one side, qualitative methods can bring to the fore how participants' discourse changes before and after PES implementation, and in doing so it can make explicit which moderators play a role in participants' behaviour and motivational change, and how these moderators relate to PES design and implementation features. On the other, experimental designs in hypothetical implementation scenarios can also aid PES design by identifying which moderators lead to increased conservation outcomes, including once payments are removed. It is our view, however, that combining research methods should improve the external validity of framed field experiments, which are still widely criticized of being unable to capture real life decision settings (Baylis et al., 2016). Probably, to avoid the bias of fictitious experimental settings, experiments need to be within real environmental programmes (Byerly et al., 2018).

Future research should also consider the interaction between moderators and the role of the larger context. Because a PES participant is exposed simultaneously to different implementation mechanisms, both extrinsic and intrinsic motivations coexist, with, ultimately, a net change towards an increase in extrinsic or intrinsic motivations. How this interaction and evaluation outcome happens needs to be better described. Seemingly, if the role of the context is not well analysed, the same PES design can unchain different and unexpected changes in motivations (Alix-Garcia et al., 2018). In addition to understanding local levels of trust and social capital in order to be able to design better PES programme or to highlight how such programme might result or not in motivational crowding, becoming aware of changing markets for local goods and services or evolving philosophical and existential values among PES participants and beyond is also critical (Singh, 2015). For practitioners, this means to invest more in socio-economic and feasibility studies before they rush into PES design and implementation. While NGOs may be constrained by donors' limited funds and willingness to see results delivered in a short time (3 to 4 years), investing more effort and time ex ante will increase efficiency (increased impacts and decreased costs) ex post.

Finally, because of the co-existence of extrinsic and intrinsic motivations during PES implementation, their impact on conservation behaviour is difficult to isolate when payments are ongoing. Our conceptual framework posits that the impact of a change in motivations will be better revealed in the long term, after payments stop. This long term effect of motivations on actual conservation behaviour has been largely overlooked by PES research and, in a context where financial constraints might dramatically limit PES funding and therefore the number of PES 
beneficiaries, better understanding if and how the undermining effect happens can be crucial to increase the efficiency of environmental incentives. This is a critical research issue. For framed field experiments it means running a post-treatment game on both control and treated populations (Andersson et al., 2018), and in quasi-experimental and other real-life evaluations, this means to develop panel data approaches to analyse the behaviour and motivations of those who stopped participating in the programme or were left-out. This will allow investigating the potentially significant lagged effect of motivations on conservation behaviour.

\section{Acknowledgements}

This article and the accompanying special issue are part of the INVALUABLE project (Values, Markets, and Policies for Biodiversity and Ecosystem Services), funded by the 2011 ERA-Net BiodivERsA programme. DEdB and RL acknowledge the contribution of the French Agence Nationale de la Recherche and the Spanish Ministry of Economics and Competitiveness, under grant numbers Convention 2011-EBID-003-01 and PRI-PIMBDV-2011-1072, respectively. EC also acknowledges the financial support of the UAB-Talent Retention Programme and notes that this work contributes to ICTA-UAB "Unit of Excellence" (MinECo, MDM2015-0552).

\section{References}

d'Adda, G., 2011. Motivation crowding in environmental protection: evidence from an artefactual field experiment. Ecol. Econ. 70(11): 2083-2097.

Agarwal, C., Tiwari, S., Borgoyary, M., Acharya, A., Morrison, E. 2007. Fair deals for watershed services in India. Natural Resource Issues no. 10. International Institute for Environment and Development. London, UK.

Agrawal, A., Chhatre, A., Gerber, E. 2015. Motivational Crowding in Sustainable Development Interventions. American Political Science Review, 109(3): 470-487.

Ajzen, I. 1991. The theory of planned behavior. Organ. Behav. Hum. Decis. Process. 50: 179-211.

Alix-Garcia, J.M.., Sims, K.R.E., Orozco-Olvera, V.H., Costica, L.E., Fernández-Medina, J.D., RomoMonroy, S. 2018. Payments for environmental services supported social capital while increasing land management Proceedings of the National Academy of Sciences. 10.1073/pnas.1720873115.

Andersson, K.P., Cook, N.J., Grillos, T., Lopez, M.C., Salk, C.F., Wright, G.D., Mwangi, E. 2018. Experimental evidence on payments for forest commons conservation. Nature Sustainability. Vol 1: 128-135.

Arsel, M., Buscher, B. 2012. NatureTM Inc.: Changes and Continuities in Neoliberal Conservation and Market-based Environmental Policy. Development and Change 43(1): 53-78.

Baumeister, R., Leary, M.R. 1995. The need to belong: Desire for interpersonal attachments as a fundamental human motivation. Pyschological Bulletin 117: 497-529.

Baylis, K. , Honey-Rosés, J. , Börner, J. , Corbera, E. , Ezzine-de-Blas, D. , Ferraro, P. J., Lapeyre, R. , Persson, U. M., Pfaff, A., Wunder, S. 2016. Mainstreaming Impact Evaluation in Nature Conservation. Conservation Letters, 9: 58-64.

Börner J., Baylis K., Corbera E., Ezzine-de-Blas D., Ferraro P.J., Honey-Rosés, J., et al. 2016. Emerging Evidence on the Effectiveness of Tropical Forest Conservation. PLoS ONE 11(11): e0159152.

doi:10.1371/journal.pone.0159152 
Börner, J., Baylis, K., Corbera, E., Ezzine-de-Blas, D., Honey-Rosés, J., Persson, M., Wunder, S. 2017. The Effectiveness of Payments for Environmental Services. World Development 96: 359-374.

Borrego, A., Skutsch, M. 2014. Estimating the opportunity costs of activities that cause degradation in tropical dry forest: Implications for REDD+. Ecological Economics 101: 1-9.

Bottazzi, P., Wiik, E., Crespo, D., Jones, J.P.G. 2018. Payment for Environmental "Self-Service": Exploring the Links Between Farmers' Motivation and Additionality in a Conservation Incentive Programme in the Bolivian Andes. Ecological Economics 150: 11-23.

Bowles, S. 2008. Policies designed for self-interested citizens may undermine "the moral sentiments": Evidence from economic experiments. Science 320: 1605-1609.

Bowles, S., Polonía-Reyes, S. 2012. Economic incentives and social preferences: substitutes or complements? Journal of Economic Literature 50(2): 368-425.

Bracht, J., Feltovich, N. 2008. Efficiency in the trust game: an experimental study of precommitment. International Journal of Game Theory 37: 39-72.

Brekke, K.A., Kverndokk, S., Nyborg, K. 2003. An economic model of moral motivation. Journal of Public Economics, 87(9-10): 1967-1983.

Brimont, L., Ezzine-de-Blas, D., Karsenty, A. 2017. The cost of making compensation payments to local forest populations in a REDD+ pilot project in Madagascar. Madagascar Conservation \& Development 12 1. http://dx.doi.org/10.4314/mcd.v12i1.3.

Byerly, H., Balmford, A., Ferraro, P.J., Wagner, C.H., Palchak, E., Polasky, S., Ricketts, T.H., Schwartz, A.J., Fisher, B. 2018. Nudging pro-environmental behavior: evidence and opportunities. Frontiers in Ecology and the Environment 16(3): 159-168.

Claassen, R., Cattaneo, A., Johansson, R. 2008. Cost-effective design of agri-environmental payment programs: U.S. experience in theory and practice. Ecological Economics 65: 737-752.

Clements, T., John, A., Nielsen, K., An, D., Tan, S., Milner-Gulland, E.J. 2010. Payments for biodiversity conservation in the context of weak institutions: Comparison of three programmes from Cambodia. Ecological Economics 69: 1283-1291.

Corbera, E, Brown, K, Adger, N. 2007. The equity and legitimacy of markets for ecosystem services. Development and Change 38(4): 587-613.

Costedoat, S., Koetse, M., Corbera, E., Ezzine-de-Blas, D. 2016. Cash only? Unveiling preferences for a PES contract through a choice experiment in Chiapas, Mexico. Land Use Policy 58: 302-317.

De Charms, R. 1968. Personal Causation: The Affective Determinants of Behavior. New York: Academic Press.

De Martino, S., Kondylis, F., Pagiola, S., Zwager, A. 2016. Do they do as they say? Stated versus revealed preferences and take up in an incentives for conservation programme. Payments for Environmental Services (PES) learning paper; no. 2015-1. World Bank Group.

Deci, E.L. 1975. Intrinsic Motivation. New York: Plenum 
Deci, E.L., Ryan, R.M. 1991. A motivation approach to self: integration in personality. In R.

Dienstbier (ed.), Nebraska Symposium on Motivation: Perspectives on Motivation 38:237-288.

Lincoln, NE: University of Nebraska Press.

Deci, E.L., Koestner, R., Ryan, R.M.. 1999 A meta-analytic review of experiments examining the effects of extrinsic rewards on intrinsic motivation. Psychological Bulletin 125(6): 627-668.

Deci, E.L., Vansteenkiste M. 2004. Self-determination theory and basic need satisfaction: Understanding human development in positive psychology. Ricerche di Psicologia 1(27): 23-40.

Dedeurwaerdere, T., Admiraal, J., Beringer, A., Bonaiuto, F., Cicero, L. et al. 2016. Combining internal and external motivations in multi-actor governance arrangements for biodiversity and ecosystem services. Environmental Science \& Policy 58: 1-10.

Dickinson, D., Villeval, M.C. 2008. Does monitoring decrease work effort? The complementarity between agency and crowding out theories. Games and Economic Behavior 63(1): 56-76.

Ellingsen, T., Johannesson, M. 2008. Pride and prejudice: the human side of incentive theory. American Economic Review 98(3): 990-1008.

Engel, S., Pagiola, S., Wunder, S. 2008. Designing payments for environmental services in theory and practice: An overview of the issues. Ecological economics 65: 663-674.

Engel, S. 2016. The Devil in the Detail: A Practical Guide on Designing Payments for Environmental Services. International Review of Environmental and Resource Economics 9(1-2): 131-177.

Ezzine-de-Blas, D., Wunder, S., Ruiz-Pérez, M., Moreno-Sanchez, R.dP. 2016a. Global Patterns in the Implementation of Payments for Environmental Services. PLoS ONE 11(3): e0149847. doi:10.1371/journal.pone.0149847F.

Ezzine-de-Blas, D., Dutilly, C., Lara-Pulido, J.A., Le Velly, G., Guevara-Sanginés, A. 2016b. Payments for Environmental Services in a Policymix: Spatial and Temporal Articulation in Mexico. PLoS ONE 11 (4): e0152514. doi:10.1371/journal.pone.0152514

Falk, A., Kosfeld, M. 2006. The Hidden Costs of Control. American Economic Review, 96(5): 16111630.

Fehr, E., Gächter, S. 1997. How effective are trust- and reciprocity-based incentives? In A. Ben-Ner and L. G. Putterman (eds.), Economics, Values, and Organization. Cambridge: Cambridge University Press.

Fehr, E., Gächter, S. 2002. Do incentive contracts undermine voluntary cooperation? Institute for Empirical Research in Economics Working Paper. University of Zurich.

Ferraro, P., Kiss, A. 2002. Direct payments to conserve biodiversity. Science 2002: 1718-1719.

Festré, A., Garrouste, P. 2014. Theory and evidence in psychology and economics about motivation crowding out: a possible convergence? Journal of Economic Surveys 00(0): 1-18. 
Fiorillo, D. 2011. Do monetary rewards crowd out the intrinsic motivation of volunteers? Some empirical evidence for Italian volunteers. Annals of Public and Cooperative Economics 82(2): 139165.

Fisher, J. 2012. No pay, no care? A case study exploring motivations for participation in payments for ecosystem services in Uganda. Oryx 46: 45-54

Frey, B. 1992. Environmental and Resource Economics 2: 399-414.

Frey, B. 1993. Motivation as a limit to pricing. Journal of Economic Psychology 14: 635-664.

Frey, B., Oberholzer-Gee, F. 1997. The cost of price incentives: an empirical analysis of motivation crowding out. American Economic Review 87(4): 746-755.

Frey, B., Goette, L. 1999. Does Pay Motivate Volunteers? Institute for Empirical Research in Economics University of Zurich. Working Paper No. 7. https://doi.org/10.3929/ethz-a-004372692.

Frey, B., Jegen, R. 2001. Motivation crowding theory. Journal of Economic Surveys 15(5): 589-611.

Gagné, M., Forest, J. 2011. The study of compensation systems through the lens of selfdetermination theory: Reconciling 35 years of debate. Montréal: CIRANO scientific series.

García-Amado, L.R., Ruiz-Pérez, M., Barrasa-García, S. 2013. Motivation for conservation: Assessing integrated conservation and development projects and payments for environmental services in La Sepultura Biosphere Reserve, Chiapas, Mexico. Ecological Economics 89: 92-100.

Gibbons, R. 1998. Incentives in Organizations. Journal of Economic Perspectives 12(4): 115-132.

Gneezy, U., Rustichini, A. 2000. A fine is a price. Journal of Legal Studies 29(1): 1-17.

Gneezy, U., Meier, S., Rey-Biel, P. 2011. When and why incentives (don't) work to modify behavior. Journal of Economic Perspectives 25: 191-210.

Greiner, R., Gregg, D. 2011. Farmers' intrinsic motivations, barriers to the adoption of conservation practices and effectiveness of policy instruments: empirical evidence from northern Australia. Land Use Policy 28 (1): 257-265.

Grolleau, G., McCann, L.M.J. 2012. Designing watershed programmes to pay farmers for water quality services: Case studies of Munich and New York City. Ecological Economics 76: 87-94.

Hendrickson, C.Y, Corbera, E. 2015. Participation dynamics and institutional change in the Scolel Té carbon forestry project, Chiapas, Mexico. Geoforum 59: 63-72.

Heukelom, F. 2014. Behavioral Economics: A History. Cambridge: Cambridge University Press. doi:10.1017/СBO9781139600224.

Houser, D., Erte, X., McCabe, K., Smith, V. 2008. When punishment fail: research on sanctions, intentions and non-cooperation. Games and Economic Behavior 62: 509-532.

Koob, G.F. Le Moal, M. Thompson R.F., Zola, S.M. 2010. History of Behavioral Neuroscience, In Encyclopedia of Behavioral Neuroscience, edited by George F. Koob, Michel Le Moal and Richard F. 
Thompson, Academic Press, Oxford, Pages 27-44, https://doi.org/10.1016/B978-0-08-0453965.00121-4.

Kosoy, N., Martinez-Tuna, M., Muradian, R., Martinez-Alier, J. 2007. Payments for environmental services in watersheds: Insights from a comparative study of three cases in Central America. Ecological Economics 61: 446-455.

Kosoy, N., Corbera, E. 2010. Payments for ecosystem services as commodity fetishism. Ecological Economics 69: 1228-1236.

Laffont, J.J., Martimort, D. 2002. The Theory of Incentives: The Principal-Agent Model. Princeton: Princeton University Press.

Le Grand, J. 2006. Motivation, Agency, and Public Policy of Knights and Knaves, Pawns and Queens. Oxford: Oxford University Press.

Lepper, M.R., Greene, D., Nisbett, R.E. 1973. Undermining children's intrinsic interest with extrinsic reward: a test of the 'overjustification' hypothesis. Journal of Personality and Social Psychology 28: 129-137.

McAfee, K. 2012. The Contradictory Logic of Global Ecosystem Services Markets. Development and Change 43(1): 105-131.

McCauley, D.J. 2006. Selling out on nature. Nature 443: 27-28.

Meyer, J.P., Gagné, M. 2008. Employee engagement from a self-determination theory perspective. Industrial and Organizational Psychology 1: 60-62.

Muradian, R. 2013. Payments for Ecosystem Services as Incentives for Collective Action, Society \& Natural Resources: An International Journal, 26(10): 1155-1169.

Muradian, R., Arsel, M., Pellegrini, L., Adaman, F., Aguilar, B., Agarwal, B., Corbera, E., Ezzine de Blas, D., Farley, J., Froger, G., Garcia-Frapolli, E., Gómez-Baggethun, E., Gowdy, J., Kosoy, N., Le Coq, J.F., Leroy, P., May, P., Méral, P., Mibielli, P., Norgaard, R., Ozkaynak, B., Pascual, U., Pengue, W., Perez, M., Pesche, D., Pirard, R., Ramos-Martin, J., Rival, L., Saenz, F., Van Hecken, G., Vatn, A., Vira, B. and Urama, K. 2013. Payments for ecosystem services and the fatal attraction of win-win solutions. Conservation Letters 6: 274-279.

Murayama, K., Matsumoto, M., Izuma, K., Matsumoto, K. 2010. Neural basis of the undermining effect of monetary reward on intrinsic motivation. PNAS 107(49): 20911-20916.

OECD - Organisation for Economic Co-operation and Development. 2010. Paying for biodiversity. Enhancing the cost-effectiveness of payments for ecosystem services. OECD, Paris, France.

Ostrom, E. 2000. Collective action and the evolution of social norms. Journal of Economic Perspectives 14(4): 137-158.

Pascual, U., Phelps, J., Garmendia, E., Brown, K., Corbera, E., Martin, A., Gomez-Baggethun, E., Muradian, R. 2014. Social Equity Matters in Payments for Ecosystem Services. BioScience 64(11): 1027-1036. 
Peluso, N.L. 2012. What's Nature Got To Do With It? A Situated Historical Perspective on Socionatural Commodities. Development and Change 43(1): 79-104.

Rico García-Amado, L., Ruiz Pérez, M., Reyes Escutia, F., Barrasa García, S, Contreras Mejía, E. 2011. Efficiency of Payments for Environmental Services: Equity and additionality in a case study from a Biosphere Reserve in Chiapas, Mexico. Ecological Economics 70: 2361-2368.

Rico García-Amado, L., Ruiz Pérez, M., Barrasa García, S. 2013. Motivation for conservation: Assessing integrated conservation and development projects and payments for environmental services in La Sepultura Biosphere Reserve, Chiapas, Mexico. Ecological Economics 89:92-100,

Rode, J, Gómez-Baggethun, E, Krause. 2015. Motivation crowding by economic incentives in conservation policy: A review of the empirical evidence. Ecological Economics 117: 270-282,

Rodríguez-de-Francisco , J.C., Budds, J., Boelens, R. 2013. Payment for Environmental Services and Unequal Resource Control in Pimampiro, Ecuador. Society \& Natural Resources: An International Journal 26(10): 1217-1233.

Rotter, J.B. 1954. Social learning and clinical psychology. New York: Prentice-Hall.

Rotter, J.B. 1966. Generalized expectancies for internal versus external control of reinforcement. Psychological. Monographs 80(1): 1-28.

Ryan, R.M., Deci, E.L. 2000a. Self-determination theory and the facilitation of intrinsic motivation, social development, and well-being. American Psychologist 55(1): 68-78.

Ryan, R.M., Deci, E.L. 2000b. Intrinsic and extrinsic motivations: classic definitions and new directions. Contemporary Educational Psychology 25: 54-67.

Sattler, C., Trampnau, S., Schomers, S., Meyer, C., Matzdorf, B. 2013. Multi-classification of payments for ecosystem services: How do classification characteristics relate to overall PES success? Ecosystem Services 6: 31-45.

Schlüter, M., Baeza, A., Dressler, G., Frank, K., Groeneveld, J., Jager, W., Janssen, M.A., McAllister, R.R.J., Müller, B., Orach, K., Schwarz, N., Wijermans, N. 2017. A framework for mapping and comparing behavioural theories in models of social-ecological systems. Ecological Economics 131: 21-35.

Singh, N.M. 2015. Payments for ecosystem services and the gift paradigm: Sharing the burden and joy of environmental care. Ecological Economics 117: 53-61.

Solarte, A. 2013. Consolidating a Model for the Payment of Environmental Services in Nasa - Paez Indigenous Communities of Morales in Colombia. CIPAV unpublished report. Web access:

http://www.cepf.net/SiteCollectionDocuments/tumbes choco/FinalReport Cipav EnvironmentalS ervicesMoralesColombia.pdf

Sommerville, M., Jones, J.G.P., Rahajaharison, M., Milner-Gulland, E.J. 2010. The role of fairness and benefit distribution in community-based Payment for Environmental Services interventions: A case study from Menabe, Madagascar. Ecological Economics 69: 1262-1271.

Steg, L., Vlek, C. 2009. Encouraging pro-environmental behaviour: an integrative review 
and research agenda. Journal of Environmental Psychology 29(3): 309-317.

Stern, P.C., Dietz, T., Abel, T., Guagnano, G.A., Kalof, L. 1999. A Value-Belief-Norm Theory of Support for Social Movements: The Case of Environmentalism. Human Ecology Review 6(2):81-97.

Tacconi, L. 2012. Redefining payments for environmental services. Ecological Economics 73: 29-36.

Thaler, R.H. 2015. Misbehaving: The Making of Behavioral Economics. New York: W. W. Norton \& Company.

Thomas, .KW. 2009. The four intrinsic rewards that drive employee engagement. Ivey Business Journal 73(6): 1-12.

Titmuss, R. 1971. The Gift Relationship: From Human Blood to Social Policy. New York: Pantheon Books.

World Bank. 2015. World Development Report 2015: Mind, Society, and Behavior. Washington, DC: World Bank. doi: 10.1596/978-1-4648-0342-0.

Wunder, S. 2015. Revisiting the concept of payments for environmental services. Ecological Economics 117: 234-243.

Wünscher, T., Engel, S., Wunder, S. 2008. Spatial targeting of payments for environmental services: A tool for boosting conservation benefits. Ecological Economics 65: 822-833. 


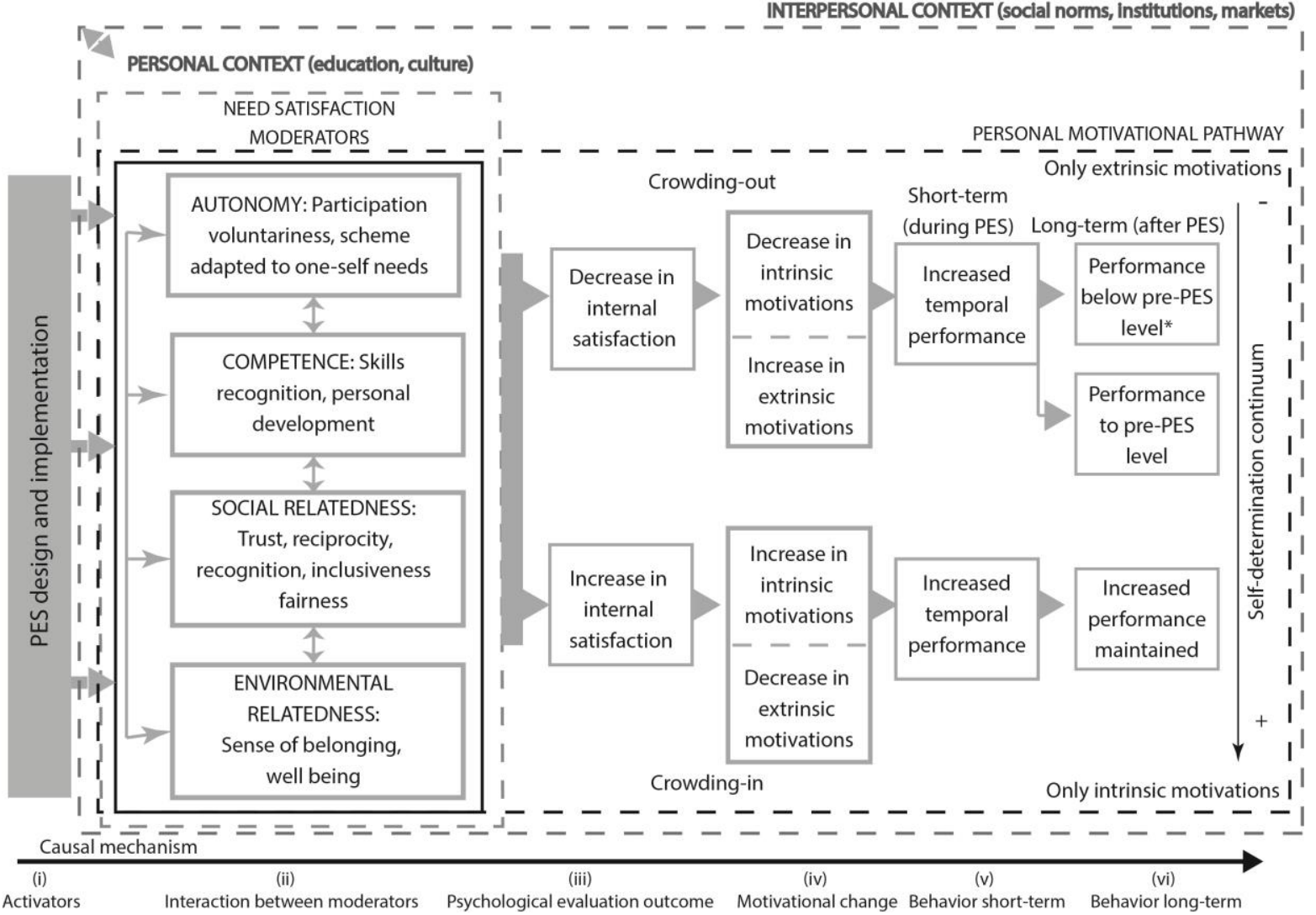

Figure 1. Motivation crowding pathways in PES. The asterisk $\left({ }^{*}\right)$ indicates the undermining effect. 
Table 1. Description of SDT moderators deployed to operationalize PES impacts on motivations.

\begin{tabular}{|c|c|c|}
\hline Moderator & Sub-moderator & Description \\
\hline Competence & $\begin{array}{l}\text { Recognition of skills } \\
\text { Personal development }\end{array}$ & $\begin{array}{l}\text { Recognition of skills relates to taking into consideration the human } \\
\text { capacities that a participant has to support the design and } \\
\text { implementation of the PES programme. } \\
\text { Personal development refers to the alignment of PES actions with the } \\
\text { wills of participants' personal development. }\end{array}$ \\
\hline Autonomy & Inclusive design & $\begin{array}{l}\text { Capacity to decide whether or not be part of the design of the PES } \\
\text { programme. }\end{array}$ \\
\hline Social relatedness & $\begin{array}{l}\text { Reciprocity } \\
\text { Distributive equity } \\
\text { Social justice and fairness } \\
\text { (procedural equity) } \\
\text { Group or community } \\
\text { inclusion }\end{array}$ & $\begin{array}{l}\text { Social norm implying having a positive action towards somebody or } \\
\text { something as a response to another positive action towards oneself. } \\
\text { Such social norm applies also for hostile or negative behaviours. } \\
\text { Process for reaching an equitable allocation of goods (e.g. payments, } \\
\text { technical assistance). } \\
\text { Social justice and fairness refers to the existence of fair and just } \\
\text { relations between the individual and society -i.e. from the local to the } \\
\text { national and international scales. It refers to how PES implementation } \\
\text { affects, for example, the distribution of wealth, options for personal } \\
\text { development, and social privileges. } \\
\text { Feeling of being included and part of a group or community. }\end{array}$ \\
\hline $\begin{array}{l}\text { Environmental } \\
\text { relatedness }\end{array}$ & $\begin{array}{l}\text { Feeling of belonging } \\
\text { Well-being, awareness of } \\
\text { healthy environment }\end{array}$ & $\begin{array}{l}\text { Feeling of belonging refers to the understanding of one's identity and } \\
\text { cultural values as defined and linked by a landscape and ecosystem } \\
\text { where PES is implemented. } \\
\text { Awareness of the positive effect that the environment or ecosystem } \\
\text { protected by PES has on your health (e.g. clean water, clean air, forest } \\
\text { hiking and running). }\end{array}$ \\
\hline
\end{tabular}


Table 2. Summary of articles present in the special issue.

\begin{tabular}{|c|c|c|c|c|c|}
\hline Authors & $\begin{array}{l}\text { PES } \\
\text { environmental } \\
\text { objective }\end{array}$ & Methods \& metrics & $\begin{array}{l}\text { Operationalization of the } \\
\text { framework }\end{array}$ & Crowd out / Crowd in & Other findings \\
\hline $\begin{array}{l}\text { Kaczan, Swallow, } \\
\text { Adamowicz }\end{array}$ & $\begin{array}{l}\text { Forest } \\
\text { conservation }\end{array}$ & $\begin{array}{l}\text { FFE (modified dictator } \\
\text { game). } \\
\text { Conservation behaviour: } \\
\text { Cards representing } \\
\text { forest conversion rate. } \\
\text { Motivations: indirectly } \\
\text { measured through post- } \\
\text { treatment behaviour. }\end{array}$ & $\begin{array}{l}\text { MCOUE }=f(\text { Pay-T, Pen) } \\
\text { MCOUE: Undermining effect } \\
\text { measured as conservation } \\
\text { behaviour in the experiment. } \\
\text { Pay-T: Collective PES, individual } \\
\text { PES or mandatory conservation. } \\
\text { Pen: Penalty in the mandatory } \\
\text { conservation. }\end{array}$ & $\begin{array}{l}\text { Average treatment effect: } \\
\text { No evidence under PES } \\
\text { treatment. } \\
\text { Strong } \mathrm{MCl} \text { under } \\
\text { mandatory treatment. }\end{array}$ & $\begin{array}{l}\text { Heterogeneity analysis: } \\
\text { Individual PES: suggestive } \\
\text { MCO for big landowners not } \\
\text { born in the village. } \\
\text { Mandatory: MCO and MCI co- } \\
\text { exist but MCI much stronger } \\
\text { for older wealthy landowners. }\end{array}$ \\
\hline $\begin{array}{l}\text { Handberg and } \\
\text { Angelsen }\end{array}$ & $\begin{array}{l}\text { Forest } \\
\text { conservation }\end{array}$ & $\begin{array}{l}\text { FFE (common pool } \\
\text { resource game). } \\
\text { Conservation behaviour: } \\
\text { Cards representing tree } \\
\text { extraction. } \\
\text { Motivations: Post } \\
\text { experimental survey on } \\
\text { conservation attitudes. } \\
\text { External validity } \\
\text { analysis. }\end{array}$ & $\begin{array}{l}\text { MCO = f (Pay-L, Comp, SocR, EnvR, } \\
\text { SocR-F) } \\
\text { MCO: Motivation crowding-out } \\
\text { measured as conservation } \\
\text { behaviour in the experiment. } \\
\text { Pay-L: Payment level. } \\
\text { Comp: Competence. } \\
\text { SocR: Social relatedness as } \\
\text { presence of relatives in the } \\
\text { experiment. } \\
\text { EnvR: Environmental relatedness } \\
\text { as real-life forest use. } \\
\text { SocR-F: Social relatedness, fairness } \\
\text { of the scheme for poor } \\
\text { participants. }\end{array}$ & No effects on aggregate. & $\begin{array}{l}\text { Increasing payments has a } \\
\text { negative but diminishing } \\
\text { effect on harvest rates. }\end{array}$ \\
\hline $\begin{array}{l}\text { Moros, Vélez, } \\
\text { Corbera }\end{array}$ & $\begin{array}{l}\text { Watershed } \\
\text { services }\end{array}$ & $\begin{array}{l}\text { FFE (public good game } \\
\text { with threshold). } \\
\text { Conservation behaviour: } \\
\text { Land use cards }\end{array}$ & $\begin{array}{l}\text { MCO = f (Pay-L, Pay-T, Aut, Comp, } \\
\text { SocR, Pen) } \\
\text { MCO: Motivation crowding-out } \\
\text { measured as changes in intrinsic } \\
\text { motivations. }\end{array}$ & $\begin{array}{l}\text { MCO under individual } \\
\text { crop-price premium. } \\
\text { MCl when payments are } \\
\text { collective. }\end{array}$ & $\begin{array}{l}\text { Individual payments decrease } \\
\text { guilt and regret feelings and } \\
\text { foster } \mathrm{MCO} \text {. Collective } \\
\text { payments foster } \mathrm{MCl} \text { through } \\
\text { enhanced social motivations. }\end{array}$ \\
\hline
\end{tabular}




\begin{tabular}{|c|c|c|c|c|c|}
\hline & & $\begin{array}{l}\text { representing } \\
\text { deforestation for crops. } \\
\text { Motivations: Post- } \\
\text { experimental survey } \\
\text { explicitly measuring } \\
\text { motivations. }\end{array}$ & $\begin{array}{l}\text { Pay-T: Type of payment (Collective } \\
\text { or individual payment) vs crop- } \\
\text { price premium. } \\
\text { Aut: Autonomy as self- } \\
\text { endorsement of forest protection. } \\
\text { Comp: Competence as self- } \\
\text { approval. } \\
\text { SocR: Social relatedness as part of } \\
\text { fair and equitable collective action. } \\
\text { Pen: Penalty in the mandatory } \\
\text { conservation. }\end{array}$ & & \\
\hline $\begin{array}{l}\text { Kolinjivadi, } \\
\text { Charré, } \\
\text { Adamowski and } \\
\text { Kosoy }\end{array}$ & $\begin{array}{l}\text { Maintenance of } \\
\text { irrigation canals }\end{array}$ & $\begin{array}{l}\text { Framed field } \\
\text { experiment. } \\
\text { Conservation behaviour: } \\
\text { Propensity to } \\
\text { participate in collective } \\
\text { activities. } \\
\text { Motivations: Semi- } \\
\text { structured interview at } \\
\text { the end of the } \\
\text { experiment. }\end{array}$ & $\begin{array}{l}\text { MCO = f (Pay-T, Comp, SocR, } \\
\text { Contx) } \\
\text { MCO: Motivation crowding-out } \\
\text { measured as participation in } \\
\text { maintenance of collective } \\
\text { infrastructure. } \\
\text { Pay-T: Type of payment (None, } \\
\text { collective in-kind, verbal reward) } \\
\text { Comp: Competence. } \\
\text { SocR: Social relatedness in terms of } \\
\text { reciprocity. } \\
\text { Contx: Context (terms of trust in } \\
\text { local leaders). }\end{array}$ & $\begin{array}{l}\text { MCO when reward is } \\
\text { expressed as a possibility } \\
\text { at individual level. } \\
\text { MCl when in-kind } \\
\text { payments are collective } \\
\text { and are given under a } \\
\text { strong feeling of } \\
\text { reciprocity and a context } \\
\text { of trusted local } \\
\text { leadership. }\end{array}$ & $\begin{array}{l}\mathrm{MCl} \text { also happens when } \\
\text { individual verbal rewards } \\
\text { foster recognition by local } \\
\text { leaders. }\end{array}$ \\
\hline $\begin{array}{l}\text { Chervier, Le Velly, } \\
\text { Ezzine-de-Blas }\end{array}$ & $\begin{array}{l}\text { Forest } \\
\text { conservation }\end{array}$ & $\begin{array}{l}\text { Quasi-experimental } \\
\text { (Real setting \& } \\
\text { matching non- } \\
\text { diachronic analysis). } \\
\text { Conservation behaviour: } \\
\text { Stated forest use. } \\
\text { Motivations: Non-use } \\
\text { forest perceptions. }\end{array}$ & $\begin{array}{l}\text { MCO = } f \text { (Pay-T, EnvR, Contx) } \\
\text { MCO: Motivation crowding-out } \\
\text { measured as change in stated } \\
\text { perceptions of forest values. } \\
\text { Pay-T: Payment type in terms of } \\
\text { contractual design. } \\
\text { EnvR: Environmental relatedness } \\
\text { expressed as hoy they perceive the } \\
\text { forest. }\end{array}$ & $\begin{array}{l}\text { Strong statistically } \\
\text { significant MCO and } \\
\text { undermining effect. }\end{array}$ & $\begin{array}{l}\text { Sharp contrast between } \\
\text { forest-peoples' traditional } \\
\text { cultural values and the } \\
\text { incoming PES socio- } \\
\text { environmental semantics and } \\
\text { norms. }\end{array}$ \\
\hline
\end{tabular}




\begin{tabular}{|c|c|c|c|c|c|}
\hline & & & $\begin{array}{l}\text { Contx: Institutional and market } \\
\text { integration dynamics } \\
\text { (deforestation threats). }\end{array}$ & & \\
\hline $\begin{array}{l}\text { Bose, Garcia and } \\
\text { Vira }\end{array}$ & $\begin{array}{l}\text { Certified coffee } \\
\text { price premium }\end{array}$ & $\begin{array}{l}\text { Ethnographic analysis. } \\
\text { Conservation behaviour: } \\
\text { Level of enrolment in } \\
\text { Rainforest Alliance } \\
\text { coffee certification. } \\
\text { Motivations: Reasons to } \\
\text { enrol in the certification } \\
\text { scheme and preference } \\
\text { of cash vs in-kind } \\
\text { benefits. }\end{array}$ & $\begin{array}{l}\text { MCO = } f \text { (Pay-T, Aut, Comp) } \\
\text { MCO: Motivation crowding-out } \\
\text { measured as the shift in the type of } \\
\text { motivations that explain } \\
\text { participation. } \\
\text { Pay-T: Payment type in terms of } \\
\text { short-term vs long term. } \\
\text { Aut: Autonomy in terms of more } \\
\text { power to negotiate at state level. } \\
\text { Comp: Competence in terms of } \\
\text { increased knowledge and capacity } \\
\text { building. }\end{array}$ & $\begin{array}{l}\text { MCO and } \mathrm{MCl} \text { coexist as } \\
\text { suggested by participants' } \\
\text { statements. }\end{array}$ & $\begin{array}{l}\text { Certification activates both } \\
\text { intrinsic and extrinsic } \\
\text { motivations. Hybrid } \\
\text { motivations combining } \\
\text { economic and non-economic } \\
\text { motivations - such as } \\
\text { upgraded farm management- } \\
\text { explain participation. }\end{array}$ \\
\hline $\begin{array}{l}\text { Van Hecken, } \\
\text { Merlet, Lindtner, } \\
\text { Bastiaensen }\end{array}$ & $\begin{array}{l}\text { Agro-silvopastoral } \\
\text { services }\end{array}$ & $\begin{array}{l}\text { Agricultural-system } \\
\text { approach combined } \\
\text { with ethnographic } \\
\text { analysis. } \\
\text { Conservation behaviour: } \\
\text { Farmers' statements } \\
\text { and productive } \\
\text { trajectories. } \\
\text { Motivations: Farmers' } \\
\text { statements. }\end{array}$ & Not applied. & No effects. & $\begin{array}{l}\text { PES coalesces into a rural } \\
\text { collective territorial pathway } \\
\text { characterised by a will to } \\
\text { increase agrarian activities. }\end{array}$ \\
\hline
\end{tabular}

FFE: Framed Field Experiment; MCOuE: Motivation crowding-out, undermining effect; Pay-T: Payment type; Pen: Penalty; MCl: Motivation crowding-in; PayL: Payment level; Comp: Competence; SocR: Social relatedness; EnvR: Environmental relatedness; SocR-F: Social relatedness, fairness; Aut: Autonomy; Contx: Context. 
Table 3. Expected impact of PES design and implementation on individuals' internal satisfaction and motivations under SDT.

\begin{tabular}{|c|c|c|c|}
\hline Moderator & Sub-moderator & Design predicting motivation crowding-in & $\begin{array}{l}\text { Design predicting no effects or motivation crowding- } \\
\text { out }\end{array}$ \\
\hline Autonomy & Inclusive participation & $\begin{array}{l}\text { Bottom-up participative approach: } \\
\text { Making all stakeholders participate in the } \\
\text { design to choose the type of reward } \\
\text { (Grolleau and McCann, 2012; } \\
\text { Dedeurwaerdere et al., 2016). }\end{array}$ & $\begin{array}{l}\text { Non-participatory top-down approach (Chervier et } \\
\text { al. this issue). }\end{array}$ \\
\hline Competence & $\begin{array}{l}\text { Recognition of skills } \\
\text { Personal development }\end{array}$ & $\begin{array}{l}\text { Payments are seen by beneficiaries as a } \\
\text { recognition of their effort and know-how } \\
\text { (Bose et al.; van Hecken et al. this issue). } \\
\text { Verbal communication stating success } \\
\text { over achieving expected or higher results } \\
\text { (Kolinjivadi et al. this issue; } \\
\text { Dedeurwaerdere et al., 2016). } \\
\text { Strengthening actor competences } \\
\text { (Dedeurwaerdere et al., 2016). }\end{array}$ & $\begin{array}{l}\text { Absence of verbal rewards. } \\
\text { Boring and not aligned with personal development } \\
\text { (Hendrickson and Corbera, 2015; De Martino et al., } \\
\text { 2016). }\end{array}$ \\
\hline Social relatedness & $\begin{array}{l}\text { Reciprocity } \\
\text { Distributive equity } \\
\text { Social justice }\end{array}$ & $\begin{array}{l}\text { Adjustment of payments to performance } \\
\text { if protection is stronger than expected. } \\
\text { Favouring the most social and } \\
\text { environmental vulnerable populations } \\
\text { (Pascual et al., 2014). } \\
\text { Sanctioning free riders to create a sense } \\
\text { of justice. (Claassen et al., 2008). }\end{array}$ & $\begin{array}{l}\text { Payments not recognizing heterogeneity of } \\
\text { opportunity costs and benefiting altogether } \\
\text { beneficiaries with and without opportunity costs } \\
\text { (Rico Garcia-Amado et al., 2011). } \\
\text { Payments benefiting the richer and the most } \\
\text { powerful (Chervier et al. this issue). } \\
\text { PES participants feel frustration if free riders are not } \\
\text { controlled (Rodríguez de Francisco et al., 2013). }\end{array}$ \\
\hline
\end{tabular}




\begin{tabular}{|l|l|l|l|}
\hline & & $\begin{array}{l}\text { Aligning with trust in the collective and } \\
\text { institutions (Andersson et al., 2018; } \\
\text { Bottazzi et al., 2018; Bose et al.; van } \\
\text { Hecken et al. this issue). }\end{array}$ & \\
& $\begin{array}{l}\text { Group and community } \\
\text { inclusion }\end{array}$ & $\begin{array}{l}\text { Collective activities: collective } \\
\text { investments and monitoring, payments } \\
\text { through collective work, exchange of } \\
\text { students, conflict resolution through } \\
\text { consensus, collective festivities (Agarwal } \\
\text { et al., 2007; Sommerville et al., 2010; } \\
\text { Solarte, 2013; Agrawal et al. 2015; Moros } \\
\text { et al.; Kolinjivadi et al. this issue). }\end{array}$ & $\begin{array}{l}\text { Imposing collective benefits if strong social conflicts } \\
\text { exist within the community (Costedoat et al, 2016). } \\
\text { Individual payments conservation tasks } \\
\text { (Clements et al., 2010). }\end{array}$ \\
\hline $\begin{array}{l}\text { Environmental } \\
\text { relatedness }\end{array}$ & $\begin{array}{l}\text { Feeling of belonging } \\
\text { Well-being, awareness of } \\
\text { healthy environment }\end{array}$ & $\begin{array}{l}\text { Conservation and transmission of } \\
\text { traditional ecological knowledge. }\end{array}$ & $\begin{array}{l}\text { Environmental education meetings. } \\
\text { Open-air activities. }\end{array}$ \\
\hline
\end{tabular}

